\title{
Paper on job satisfaction of SBI EmployeesJob Satisfaction of Public Sector Bank Employees (A Case study of Udaipur and Rajsamand Districts S.B.I.)
}

\author{
Dr.M.G.Varshney, SangeetaMalpani \\ HOD Banking \\ HOD Banking B.N.girls college kankroli \\ Lecturer in Govt. Girls CollegeNathdwara \\ Research scholar CCMS Udaipur
}

\begin{abstract}
Satisfaction from life and every work is the important aim of every one's life. We spent maximum time of our in working or involving in any economic activity which is the main sources of surviving our life. Every employee wants to get higher level of satisfaction from his job. Job satisfaction is the favorableness or unfavorableness with which employees view their work. Job satisfaction is a psychological concept and it is mostly depend upon the internal feeling of employees. There are a lot of independent variables on which job satisfaction is depending. These are educational qualifications, nature of work, pay, job security, promotional opportunities and family \& work life balance. The employee's satisfaction improve the productivity and profit so it is importantboth employees and employer also.In this paper researcher tried to explain the concept and factor affecting job satisfaction and their significant relationship with all factors. The commercial banks have embarked on different management strategies as resorts to promote employees job satisfaction. The main purpose of the study is to identify the levels of job satisfaction among employees of public sector bank and the factors contributing to job satisfaction.
\end{abstract}

Keywords: dependent, employee, psychological, strategies, satisfaction, variables.

\section{Introduction}

Major part of man's life spent in work which is a social reality and social expectation. only economic motive has never satisfied men. It is always of a greater interest to know why men work and at which level and how he/she satisfied with the job.Job satisfaction is dynamic, as it can go as quickly as it comes. It is a positive emotional state that occurs when a person's job seems to fulfill important values, provided these values are compatible with one's needs. Job satisfaction is a pleasurable or positive emotional state resulting from the appraisal of one's job experience. In short job satisfaction is a synchronization of what an organization requires of its employees and what the employees are seeking of the organization.

There are many variables that have been conjecture to be a result of job satisfaction or dissatisfaction. The concept of job satisfaction has emerged and now there are several factors contributing to it which are monetary and non-monetary job satisfaction of employees and bank performance/ success are significantly related to each other. Better understanding of job satisfaction and factors associated with it helps managers to guide employee's activities in a desired direction. The morale of employees is a deciding factor in the bank efficiency. Thus, it is fruitful to say that managers, supervisors, human resource specialists, employee and citizens in general are concerned with ways of improving job satisfaction.

The study of job satisfaction among Bank employees is important because there are various aspects of the job that are highly attractive and lead to satisfaction and aspects of the job that lead to dissatisfaction. Positive aspects include the opportunity to work in Bank and employees to accomplish common goals, developing banking background and the ability to work with co-workers. It is important to identify which factors contribute to job satisfaction as well as those that may lead to job dissatisfaction to assure that the manager ship is attractive to potent. There are many variables that have been hypothesized to be a result of job satisfaction or dissatisfaction. These include both those variables of job performance and those of deem. The degree of satisfaction are determined bythe ratio between what we have and what we want. By law of nature as we have more, we want more, hence the level of satisfaction remains less.

\section{Review Literature}

Maximum time of Man's life spend at work place so a man satisfy his life if he satisfy from his job. Five components affect the job satisfaction; work, pay promotion, salary and recognition (Khalid Salman \&Irshad Muhammad, 2011)

Lethal C.(2007) indicate no direct relationship between job satisfaction and level of education .Women employees more satisfaction with their job and recognized (teaching) as their ideal profession. Married employees were found to be more satisfied than their unmarried colleagues. That the employees with higher 
rank reported less satisfaction and more dissatisfaction than those who were in the lower rank.Sargent and Hannum (2005) On the other Shah and Jalees (2004) say that job satisfaction increase as employees progrees in rank.

Alam (2013) conducted a research on the Job satisfaction of female workers in different garment factories in Dhaka city and concluded the level of satisfaction is positively correlated with level of wages they get. Zeal, Anwar and Nazrul (2012) in their study on comparative Job satisfaction of senior male and female executives in Bangladesh, showed that there are insignificant difference between male and female executives regarding satisfaction in different facets of job. The direction of all these studies on job satisfaction tends to be consistent to the self-reporting state of individual is very much related to the job itself and one's experience.

\section{OBJECTIVES}

The present study is aimed at finding out job satisfaction of bank employees through different dimension and density of satisfaction levels.

More specifically we can furnish the objectives as follows

To find out the satisfaction level of public banks regarding job aspects Sex, Age ,No of Depended, Marital status Pay, Educational level, experience, Leave facilities Other basic requirements etc.

To identify the factors responsible for satisfaction or dissatisfaction of the bank employees

\section{HYPOTHESES}

There will be a significant relationship between the variables (namely, occupational class, race, gender, educational level, experience, age, marital status, income and job status) and job satisfaction amongst employees in a public sector banks.

\section{III. significance of the study:}

We enjoy work and find it to be a central part of life, but some of us hate work and do so only because they must. Job satisfaction then can be important to those who are in an organization it allows the workers and researchers to look at aspects of job satisfaction in the organization and work to increase those aspects that lead to job satisfaction. Those who study job satisfaction in organizations do so for two reasons 1 Job satisfaction is relevant for all those who are interested in the subjective evaluation of working conditions such as responsibility, task variety, or communication requirements because job satisfaction is strongly caused by such conditions.

2 Job satisfactions is also important because it is closely linked to outcome variables such as absenteeism, inefficiency, counterproductive behavior, or lack of leadership.

\section{Methodology.}

Job satisfaction has been taken as dependent variable. Independent variables are educational qualifications, nature of work, pay, job security, promotional opportunities and no. of depended persons \& work life balance. The main purpose of the study is to identify the levels of job satisfaction among employees of private and public sector bank and the factors contributing to job satisfaction. Bank employees in this study refer to clerks, officers, and managers. To achieve the objectives of the study 150 surveys were sent (through questioners) to 15 public sector banks situated in districts of Udaipur and Rajsamand.

Therefore all the questionnaires were returned having response rate of $100 \%$. The questionnaire using 5-Scale Likert (1 Strongly satisfied, 2 Satisfied, 3 Neutral 4 Strongly dissatisfied 5 Dissatisfied ) design to test the impact of all the variables. For this study the questionnaire is divided into 2 sections demographic variables and facets of job satisfaction. The questionnaire cover all the variables such as educational qualifications, nature of work, pay, job security, promotional opportunities and no. of depended \& work environment. The data were analyzed through SPSS v.19

\section{Data Analysis and Interpretation}

It is to be recalled that the principal objectives of the present study are to study the factors affected job satisfaction of S.B.I. bank employees. Data collected with the help of questionnaire and $\square^{2}$ test is applied for the significant of variables.

According to Robbins and Sanghi (2006) "Job satisfaction is collection of feelings that an individual holds toward his or her job." The same was contributed by MasudIbn Rahman (2008) "Job satisfaction is defined as a general attitude toward one's job. It is in regard to one's feelings or state-of-mind regarding the nature of their work."

Job satisfaction is derived from many inter-related factors. Although these factors can never be completely isolated from one another for analysis, they can by the use of statistical techniques, be separated enough to give an indication of their relative importance to job satisfaction. Job satisfaction is the result of effect 
of so many factors. The terms are highly personalized, as the level of satisfaction differs from time to time and situation. Moreover, the attitude of any employee affects a lot. One gets satisfaction in any of the activities depending upon how he/she perceives the situation and what is expected in exchange of effort. There may be the difference between two employees, working at a different place and on different cadres. It all depends upon viewing of the situation and the effect of rest of the factors which are crucial at any point of time.

A) Personal Factors: Sex, Number of Dependents, Age, Educational level.

B) Factors related to the Job : Type of work, Size of organization, Pay, Opportunity for advancement, Working conditions ,Co-workers.

Table: 1 Job Satisfaction according sex

\begin{tabular}{|l|l|l|l|l|}
\hline $\begin{array}{c}\text { S. } \\
\text { N. }\end{array}$ & Satisfaction level & Male & Female & Total \\
\hline 1 & Strongly satisfied & 40 & 17 & 57 \\
\hline 2 & Satisfied & 25 & 10 & 35 \\
\hline 3 & Neutral & 5 & 5 & 10 \\
\hline 4 & Dissatisfied & 20 & 8 & 28 \\
\hline 5 & Strongly Dissatisfied & 15 & 5 & 20 \\
\hline
\end{tabular}

\begin{tabular}{|l|l|l|l|l|}
\hline$\chi^{2}$ & P value & D.F. & $\downarrow$ S.D. & $\rightarrow$ S.D. \\
\hline 2.2049 & $\mathbf{0 . 6 9 8 1 2 9}$ & 4 & $\mathbf{1 7 . 7 3 4 1}$ & $\mathbf{4 2 . 4 2 6 4}$ \\
\hline
\end{tabular}

At $5 \%$ level of significance the calculate value of $\chi^{2}$ is 2.2049 and the table value of $\chi^{2}$ is 9.48773.The calculate value is less than the table value so it conclude that there is no significant relationship between sex and job satisfaction. $\mathrm{P}>0.05$ so it is not a significant factor means job satisfaction is not related with sex. The gender variable is not significant at the $5 \%$ level.

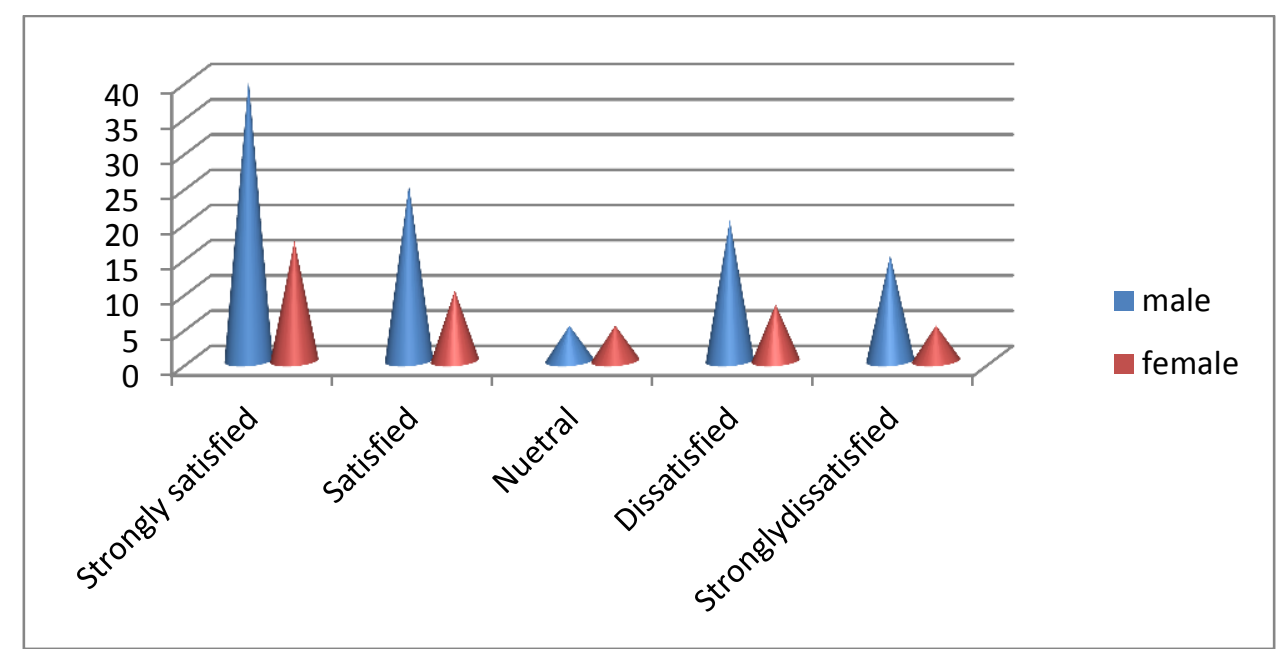

Table: 2 Job Satisfaction according No. of depends

\begin{tabular}{|l|l|l|l|l|l|}
\hline $\begin{array}{l}\text { S. } \\
\text { No. }\end{array}$ & Satisfaction Level & $1-2$ depended & $3-4$ depended & $\begin{array}{l}\text { More than } 4 \\
\text { depended }\end{array}$ & Total \\
\hline 1 & Strongly satisfied & 15 & 33 & 10 & 58 \\
\hline 2 & Satisfied & 5 & 20 & 5 & 30 \\
\hline 3 & Neutral & 5 & 9 & 3 & 17 \\
\hline 4 & Dissatisfied & 7 & 10 & 5 & 22 \\
\hline 5 & Strongly Dissatisfied & 5 & 15 & 3 & 23 \\
\hline Total & 37 & 87 & 26 & 150 \\
\hline
\end{tabular}

\begin{tabular}{|l|l|c|l|l|}
\hline$\chi^{2}$ & P value & D.F. & $\downarrow$ S.D. & $\rightarrow$ S.D. \\
\hline 3.4049 & $\mathbf{0 . 9 0 6 4 4 5 2}$ & $\mathbf{8}$ & $\mathbf{1 6 . 3 2 4 8}$ & $\mathbf{3 2 . 5 1 1 5}$ \\
\hline
\end{tabular}


At $5 \%$ level of significance the calculate value of $\chi^{2}$ is 3.4049 and the table value of $\chi^{2}$ is 15.50731 . The calculate value is lower than the table value so it conclude that there is not significant relationship between no. of depended and job satisfaction. $\mathrm{P}>0.05$ so it is a not significant variable means job satisfaction is not affected with the No .of depended.

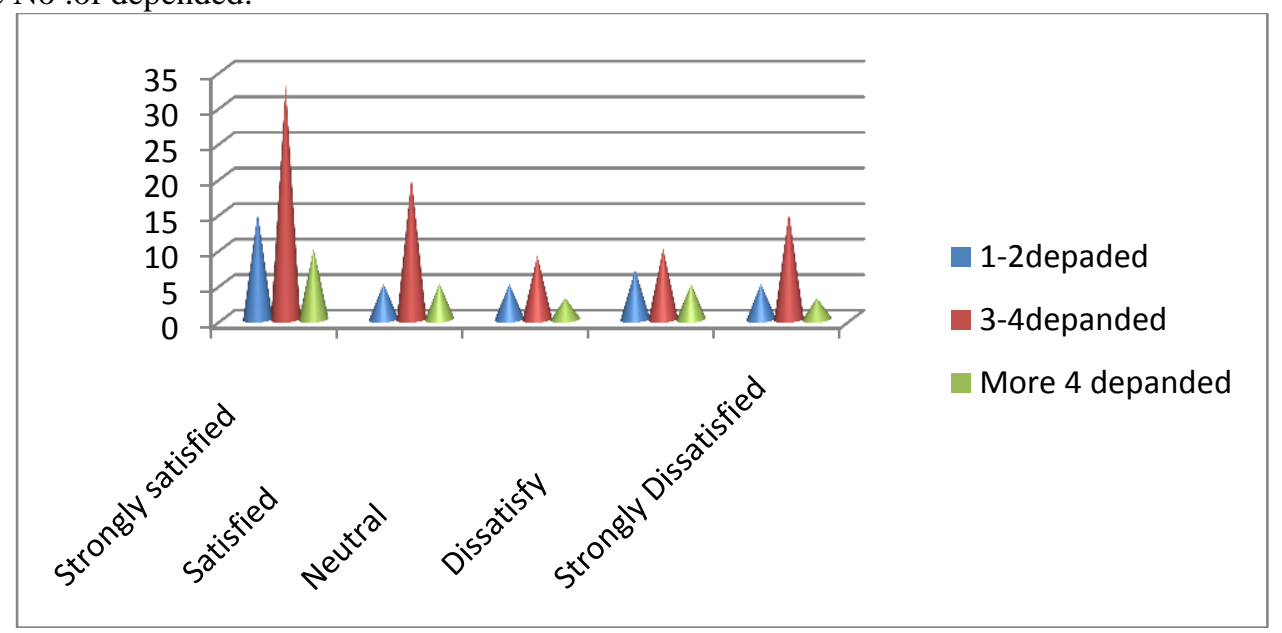

$\square$ able: 3 Job Satisfaction according marital status

\begin{tabular}{|l|l|l|l|l|}
\hline S. No. & Satisfaction Level & Married & Unmarried & Total \\
\hline 1 & Strongly satisfied & 45 & 15 & 60 \\
\hline 2 & Satisfied & 25 & 10 & 35 \\
\hline 3 & Neutral & 10 & 3 & 15 \\
\hline 4 & Dissatisfy & 20 & 10 & 30 \\
\hline 5 & Strongly Dissatisfied & 5 & 7 & 12 \\
\hline Total & 105 & 45 & 150 \\
\hline
\end{tabular}

\begin{tabular}{|l|l|l|l|l|}
\hline$\square^{2}$ & P value & D.F. & $\downarrow$ S.D. & $\rightarrow$ S.D. \\
\hline 5.7910 & $\mathbf{0 . 2 1 5 3 0 7}$ & 4 & $\mathbf{1 9 . 6 0 6 7}$ & $\mathbf{4 2 . 4 2 6 4}$ \\
\hline
\end{tabular}

At 5\% level of significance the calculate value of $\chi^{2}$ is 5.7910 and the table value of $\chi^{2} \quad 9.48773$ The calculate value is lower than the table value so it conclude that there is not significant relationship between marital status and job satisfaction. $\mathrm{P}>0.05$ so it is a not significant variable.

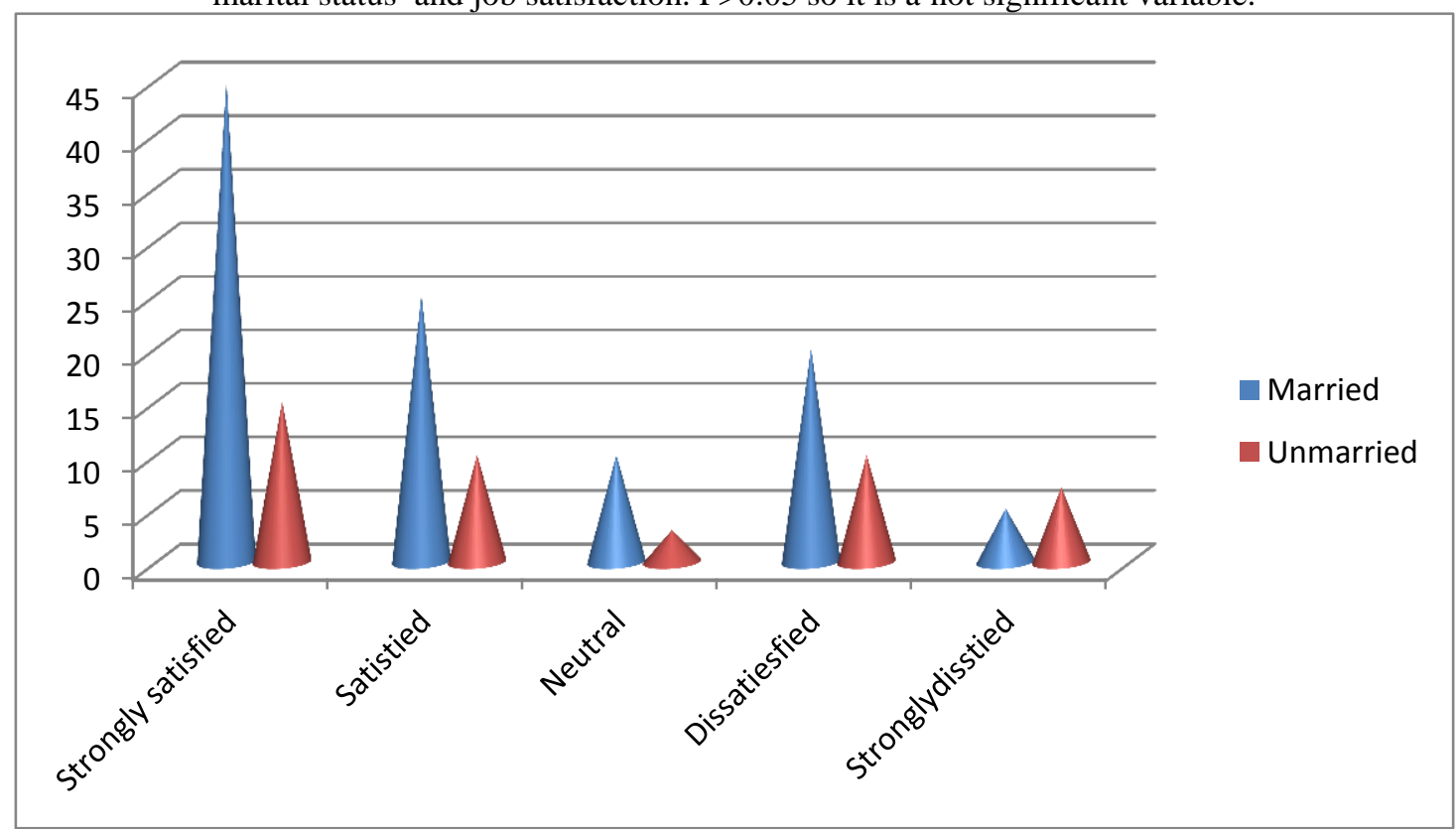

Table: 4 Job Satisfaction according educational level 


\begin{tabular}{|l|l|l|l|l|l|}
\hline $\begin{array}{l}\text { S. } \\
\text { No. }\end{array}$ & Satisfaction Level & Graduate & PG & Above PG & Total \\
\hline 1 & Strongly satisfied & 15 & 25 & 20 & 60 \\
\hline 2 & Satisfied & 10 & 15 & 18 & 43 \\
\hline 3 & Neutral & 3 & 2 & 2 & 7 \\
\hline 4 & Dissatisfy & 10 & 10 & 5 & 25 \\
\hline 5 & Strongly Dissatisfied & 7 & 5 & 3 & 15 \\
\hline
\end{tabular}

At 5\% level of significance the calculate value of $\chi^{2}$ is $\mathbf{7 . 5 2 3 6}$ and the table value of $\chi^{2 \text { is }} 15.50731$ The calculate value is lower than the table value so it conclude that there is not significant relationship between educational level and job satisfaction. $\mathrm{P}>0.05$ so it is a not significant variable

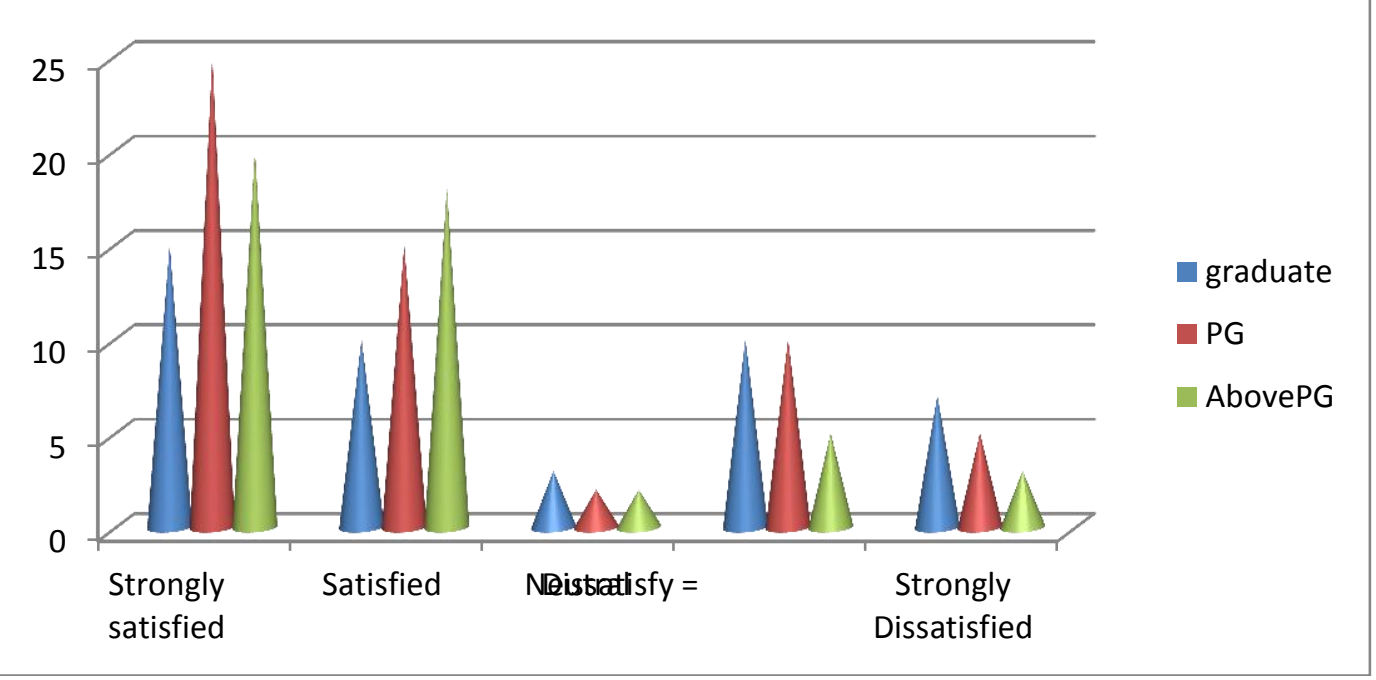

Table: 5 Job Satisfaction according Age

Age is an important factor to decide about job satisfaction. Maximum age limit for clerk and probationary officers to join bank is of 28 yrs.

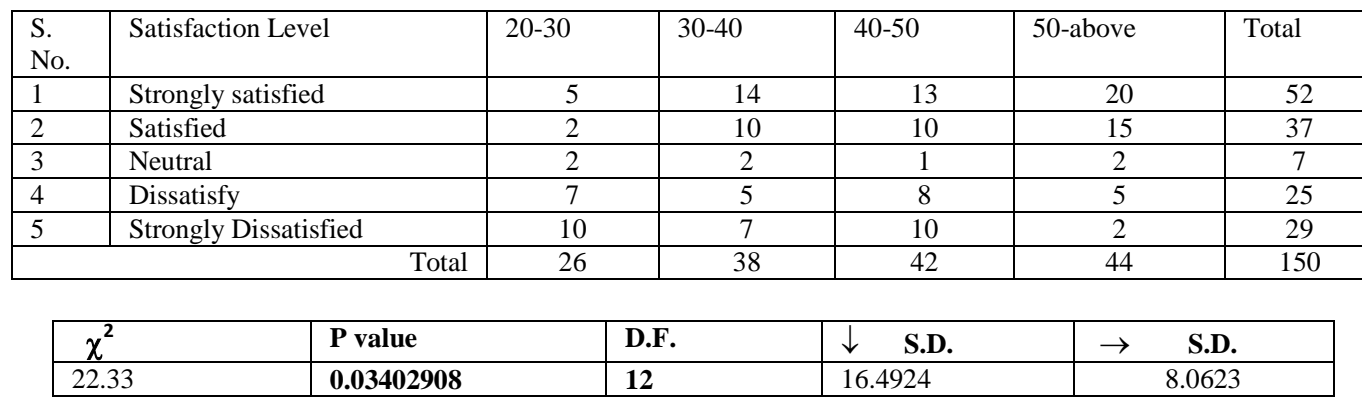

At 5\% level of significance the calculate value of $\chi^{2}$ is 22.33 and the table value of $\chi^{2}$ is 21.02607 The calculate value is higher than the table value so it conclude that there is a significant Relationship between age and job satisfaction. $\mathrm{P}<0.05$ so it is a significant variable means job satisfaction is related to age of employees 


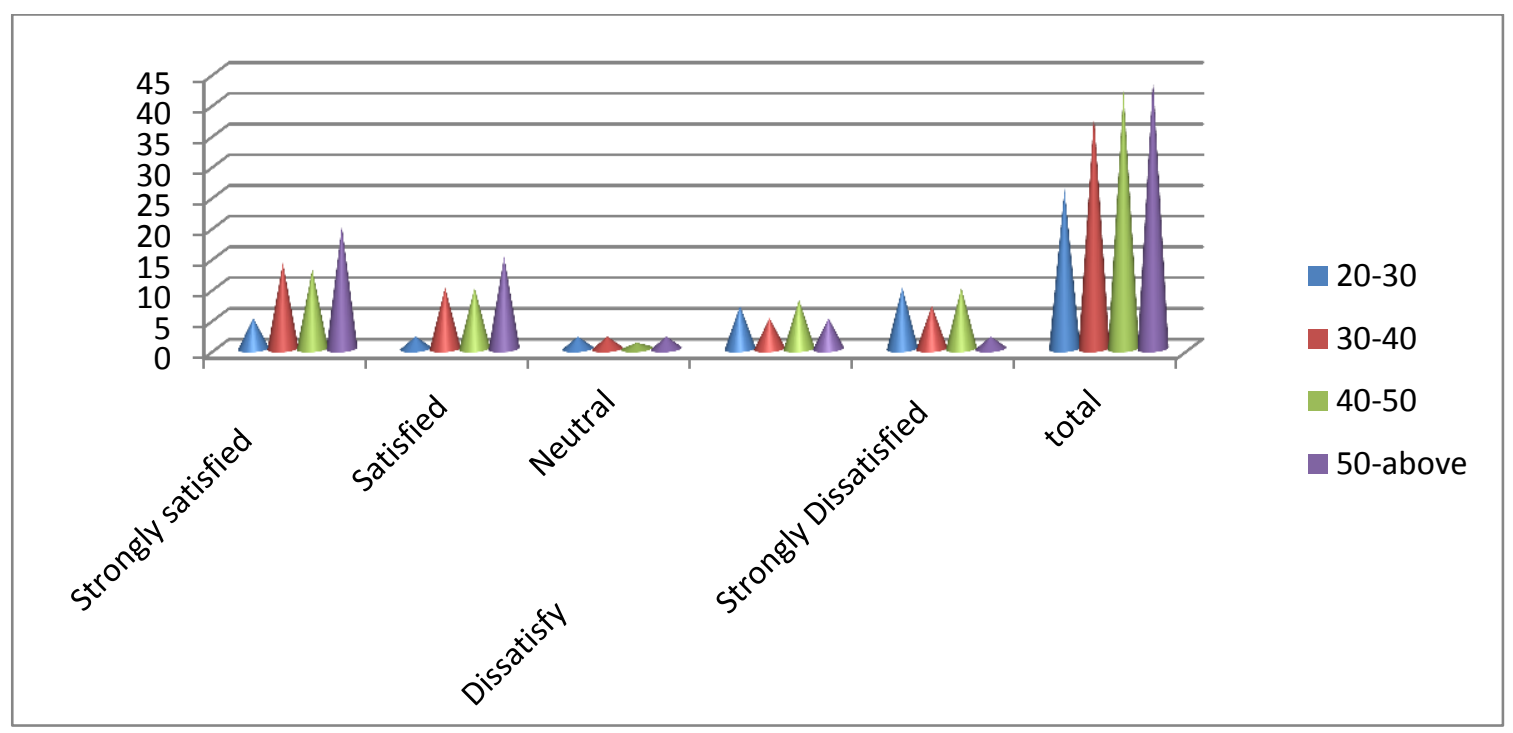

Table: 6 Job Satisfaction according Experience

\begin{tabular}{|l|l|c|c|c|c|c|c|}
\hline S. No. & Satisfaction Level & $1-5$ year & $6-10$ year & $\begin{array}{l}11-15 \\
\text { year }\end{array}$ & $16-20$ year & Above 20 & Total \\
\hline 1 & Strongly satisfied & 5 & 5 & 15 & 20 & 23 \\
\hline 2 & Satisfied & 3 & 5 & 10 & 12 & 8 \\
\hline 3 & Neutral & 3 & 2 & 1 & 2 & 2 \\
\hline 4 & Dissatisfy & 5 & 3 & 2 & 10 & 2 \\
\hline 5 & Strongly Dissatisfied & 7 & 5 & 5 & 3 & 13 \\
\hline \multicolumn{2}{r|}{ Total } & $\mathbf{2 3}$ & $\mathbf{2 0}$ & $\mathbf{3 3}$ & $\mathbf{3 9}$ & $\mathbf{3 5}$ \\
\hline
\end{tabular}

\begin{tabular}{|c|l|l|l|ll|}
\hline$\chi^{\mathbf{2}}$ & P value & D.F. & $\downarrow \quad$ S.D. & $\rightarrow$ & S.D. \\
\hline 31.03 & $\mathbf{0 . 0 1 3 4}$ & $\mathbf{1 6}$ & 23.8642 & 8.1240 & \\
\hline
\end{tabular}

At 5\% level of significance the calculate value of $\chi^{2}$ is 31.03 and the table value of $\chi^{2}$ is 26.29623 The calculate value is higher than the table value so it conclude that there is not a significant Relationship between experience and job satisfaction. $\mathrm{P}>0.05$ so it is not a significant variable means job satisfaction is related with Experience. This variable is significant at the $5 \%$ level.

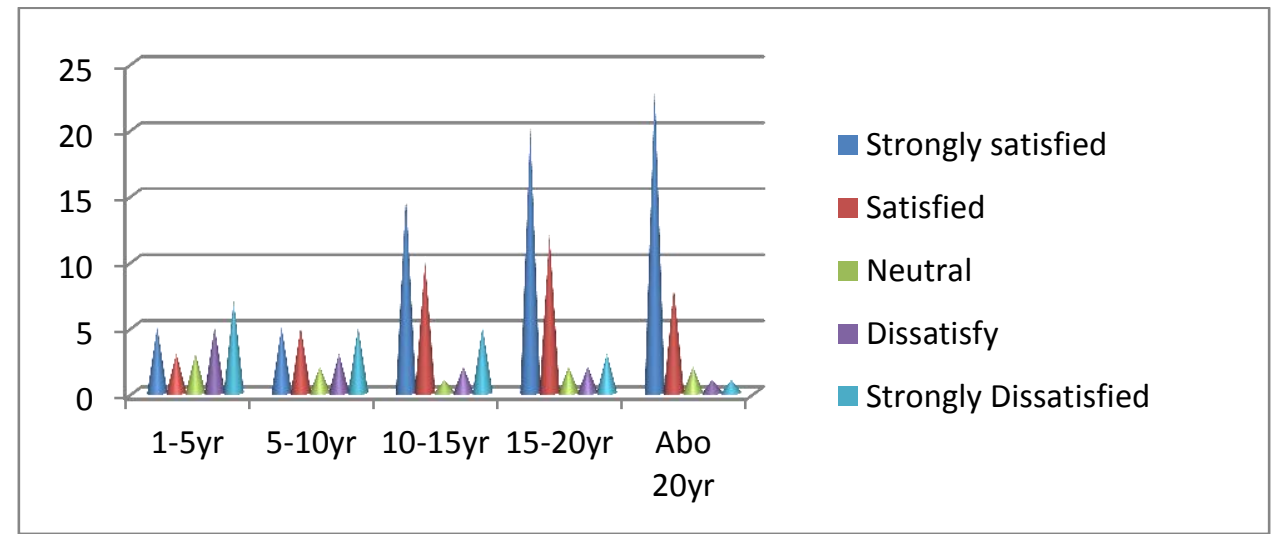

Table: 7 Job Satisfaction according Leave facilities

\begin{tabular}{|l|l|c|c|c|c|}
\hline $\begin{array}{l}\text { S. } \\
\text { No. }\end{array}$ & Satisfaction Level & ML & PL & CL & Total \\
\hline 1 & Strongly satisfied & 40 & 35 & 20 & 95 \\
\hline 2 & Satisfied & 38 & 30 & 17 & 85 \\
\hline 3 & Neutral & 14 & 20 & 25 & 59 \\
\hline 4 & Dissatisfy & 25 & 36 & 40 & 101 \\
\hline 5 & Strongly Dissatisfied & 33 & 29 & 48 & 110 \\
\hline \multicolumn{2}{|r|}{ Total } & 150 & 150 & 150 & 450 \\
\hline
\end{tabular}




\begin{tabular}{|c|c|c|c|c|}
\hline$x^{2}$ & \begin{tabular}{|l} 
value \\
\end{tabular} & D.F. & $\begin{array}{ll}\downarrow & \text { S.D. }\end{array}$ & $\rightarrow$ \\
\hline 26.9131 & \begin{tabular}{|l|}
0.000732 \\
\end{tabular} & 8 & $\begin{array}{l}19.5704 \\
\end{array}$ & 0.0000 \\
\hline
\end{tabular}

At 5\% level of significance the calculate value of $\chi^{2}$ is 26.9131 and the table value of $\chi^{2}$ is 15.50731 the calculate value is more higher than the table value so it conclude that there is a significant relationship between Leave facilities and job satisfaction. $\mathrm{P}<0.05$ so it is a significant variable means job satisfaction is related to leave facilities which are given by bank.

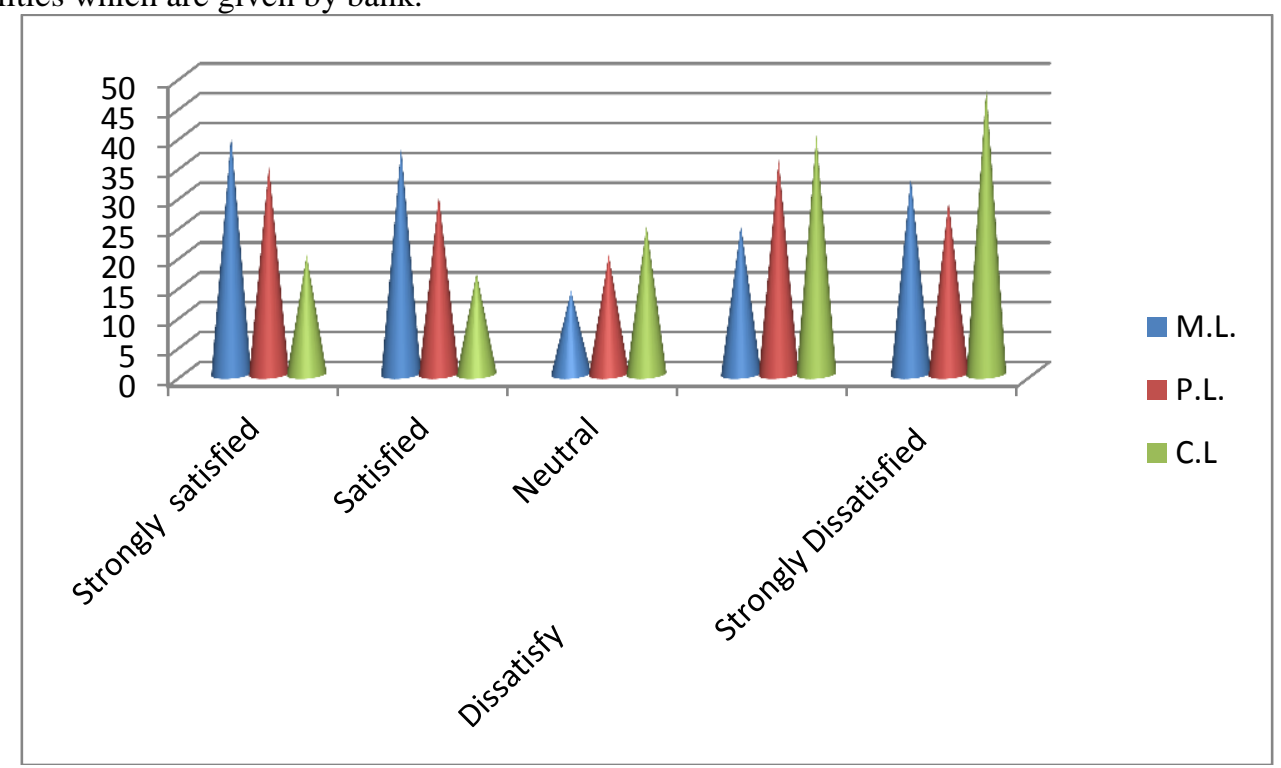

Table: 8 job Satisfaction according other basic requirement/ other facilities

\begin{tabular}{|l|l|c|c|c|c|c|}
\hline $\begin{array}{l}\text { S. } \\
\text { No. }\end{array}$ & Satisfaction Level & A/C & Water & Computer & Electricity & Total \\
\hline 1 & Strongly satisfied & 30 & 35 & 25 & 30 & 120 \\
\hline 2 & Satisfied & 25 & 40 & 30 & 20 & 115 \\
\hline 3 & Neutral & 20 & 15 & 10 & 15 & 30 \\
\hline 4 & Dissatisfy & 40 & 25 & 35 & 50 & 135 \\
\hline 5 & Strongly Dissatisfied & 35 & 35 & 50 & 150 & 150 \\
\hline \multicolumn{2}{|r|}{ Total } & 150 & 150 & & & 600 \\
\hline
\end{tabular}

\begin{tabular}{|l|l|l|c|l|}
\hline$\chi^{2}$ & P value & D.F. & S.D. & $\rightarrow \quad$ S.D. \\
\hline $\mathbf{2 1 . 4 2 1 3}$ & $\mathbf{0 . 0 4 4 5 4 0 8 2}$ & $\mathbf{1 2}$ & 39.8434 & 0.00000 \\
\hline
\end{tabular}

At 5\% level of significance the calculate value of $\chi^{2}$ is 21.4213 and the table value of $\chi^{2}$ is 21.02607 The calculate value is higher than the table value so it conclude that there is a significant relationship between other facilities and job satisfaction. $\mathrm{P}<0.05$ so it is a significant variable means job satisfaction is related with other basic requirement.

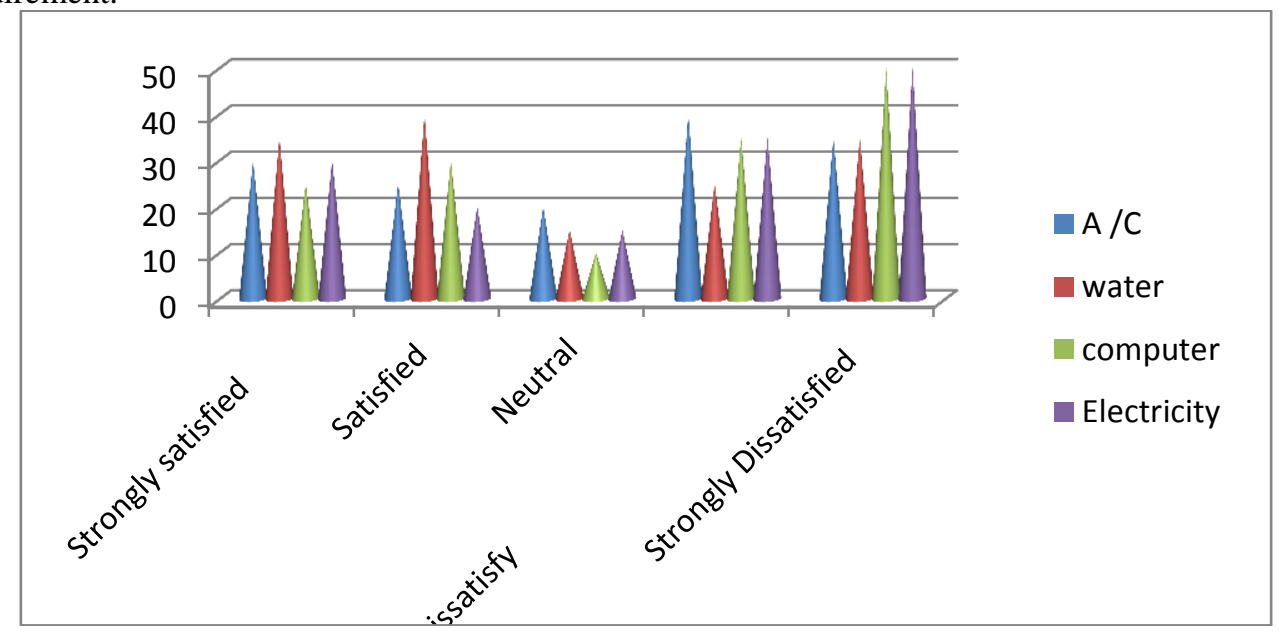


Table: 9 Job Satisfaction according working hours

\begin{tabular}{|l|l|c|c|r|}
\hline $\begin{array}{l}\text { S. } \\
\text { No. }\end{array}$ & Satisfaction Level & $\begin{array}{l}6-8 \\
\text { hours }\end{array}$ & $\begin{array}{l}\text { More } \\
\text { than } 8 \\
\text { hr }\end{array}$ & Total \\
\hline 1 & Strongly satisfied & 45 & 10 & 55 \\
\hline 2 & Satisfied & 40 & 7 & 47 \\
\hline 3 & Neutral & 25 & 6 & 31 \\
\hline 4 & Dissatisfy & 10 & 1 & 11 \\
\hline 5 & Strongly Dissatisfied & 5 & 1 & 6 \\
\hline \multicolumn{2}{r|}{} & 125 & 25 & 150 \\
\hline
\end{tabular}

\begin{tabular}{|l|l|l|l|l|}
\hline$\chi^{2}$ & P value & D.F. & $\downarrow \quad$ S.D. & $\rightarrow$ S.D. \\
\hline $\mathbf{1 1 . 7 3 7 8}$ & $\mathbf{0 . 0 1 9 4 1 1}$ & $\mathbf{4}$ & 16.02 & 16.02 \\
\hline
\end{tabular}

At $5 \%$ level of significance the calculate value of $\chi^{2}$ is 11.7378 and the table value of $\chi^{2}$ is $9.48773 \square \square$ he calculate value is higher than the table value so it conclude that there is a significant Relationship between working hours and job satisfaction. $\mathrm{P}<0.05$ so it is a significant variable means job satisfaction is related to working hour of bank.

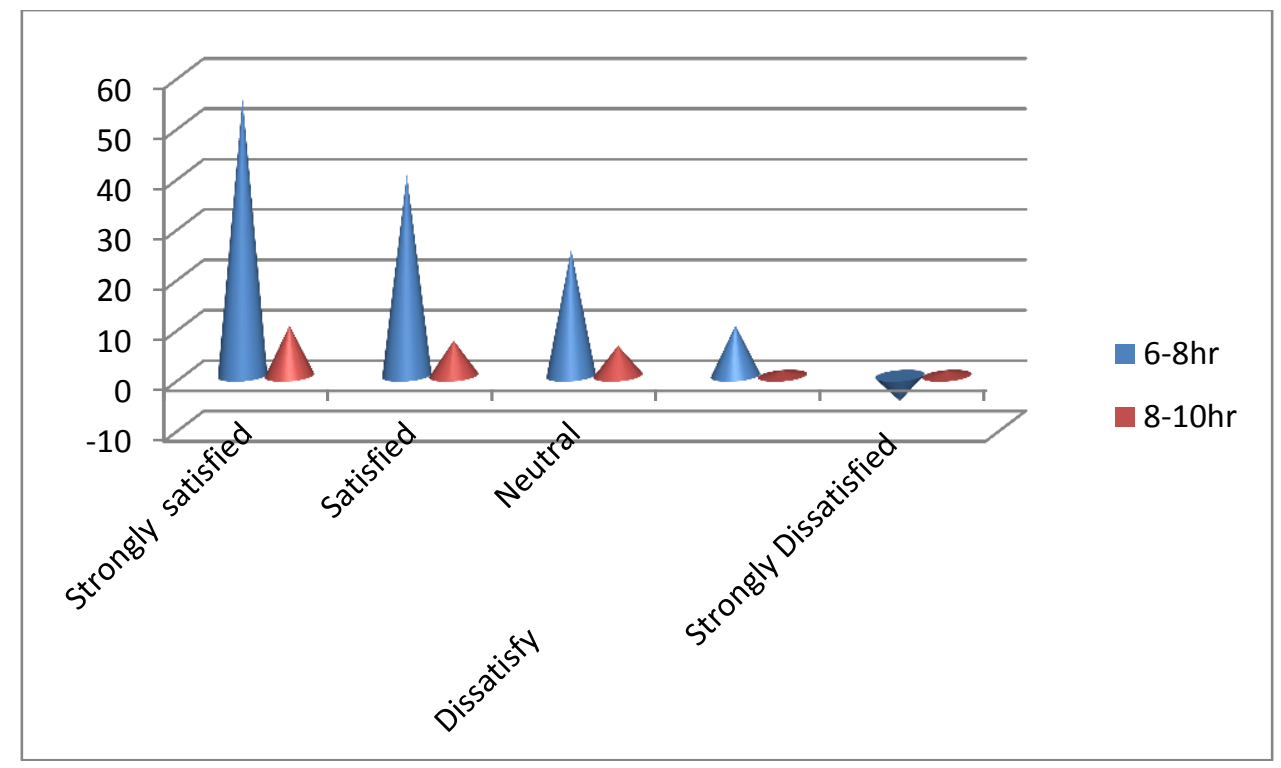

Table:10 Satisfaction according Package

\begin{tabular}{|l|l|c|c|c|c|c|}
\hline S. No. & Satisfaction Level & $1-2$ lakh & $2-3$ lakh & $3-4$ lakh & Above 4 lakh & Total \\
\hline 1 & Strongly satisfied & 4 & 20 & 25 & 2 \\
\hline 2 & Satisfied & 5 & 18 & 20 & 31 \\
\hline 3 & Neutral & 3 & 5 & 3 & 1 \\
\hline 4 & Dissatisfy & 2 & 9 & 10 & 3 \\
\hline 5 & Strongly Dissatisfied & 4 & 4 & 3 & 24 \\
\hline \multicolumn{2}{r|}{ Total } & 18 & 56 & 61 & 6 \\
\hline
\end{tabular}

\begin{tabular}{|l|l|l|l|l|}
\hline$\chi^{2}$ & P value & D.F. & S.D. $\downarrow$ & $\rightarrow$ S.D. \\
\hline 23.0522 & $\mathbf{0 . 0 2 7 2 8 6}$ & $\mathbf{1 2}$ & 17.5071 & 24.3653 \\
\hline
\end{tabular}

At 5\% level of significance the calculate value of $\chi^{2}$ is 23.0522 and the table value of $\chi^{2}$ is 21.02607 The calculate value is higher than the table value so it conclude that there is a significant Relationship between package and job satisfaction. . $\mathrm{P}<0.05$ so it is a significant variable means job satisfaction is related to Package 


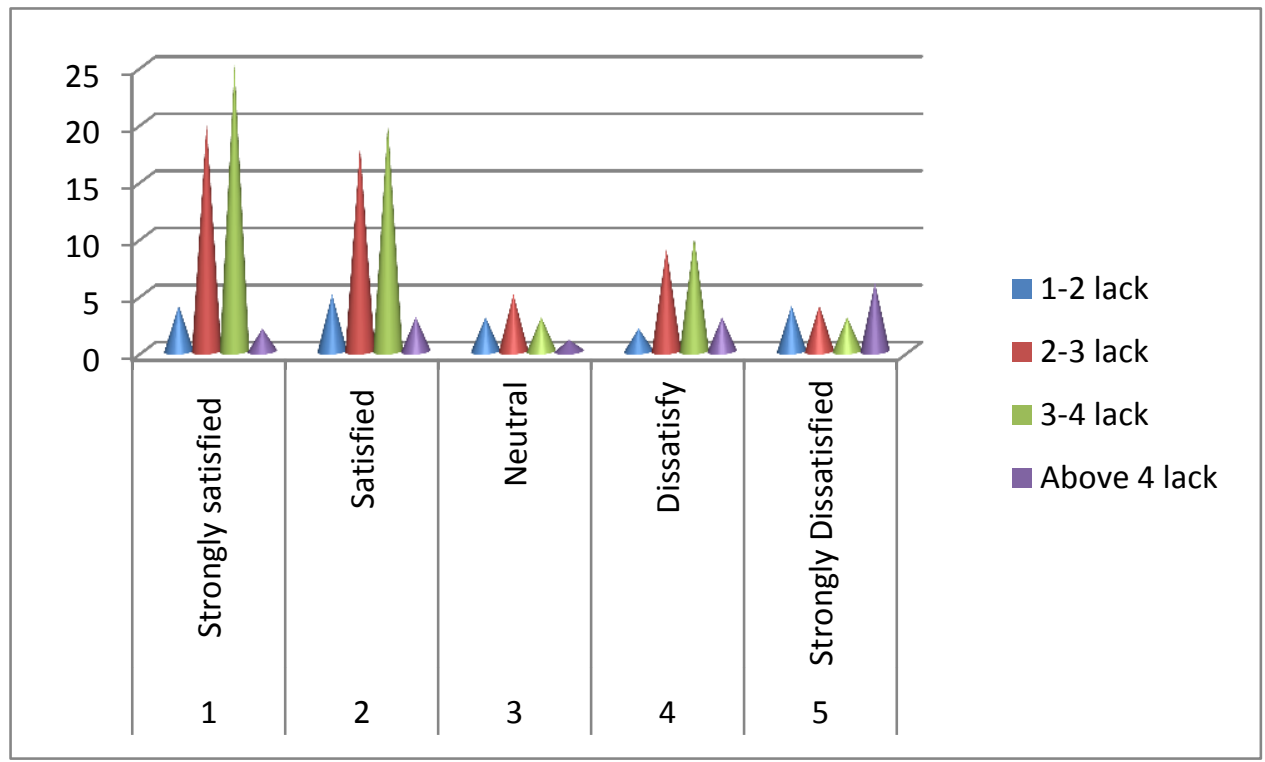

\section{Conclusions}

The purpose of this study was to investigate the predictors of bank employees. Job satisfaction including those that are personal and those that are job related in the Udaipur and Rajsamnd Job satisfaction has been one of the most extensively researched concepts in work and organizational psychology. Job satisfaction is believed to reflect an individual's affective and/or cognitive assessment of his or her working conditions and job attributes. It has been traditionally used to confirm the effectiveness of job redesign and motivational conditions at work. The dimensions and degree of job satisfaction of bank employees of Udaipur and Rajsamand are not uniform. However after introspecting several of parameters and dimensions, it becomes clear that no single dimension or factor can please human being totally. More over satisfaction is a state of mind.

\section{References}

[1]. Alam (2013) “Wages and Employees Satisfaction” Management and LabourStidies. 23(3), pp. $421-427$.

[2]. Bajpai, N., \&Srivastava, D. (2004). Sectorial comparison of factors influencing job satisfaction in Indian banking sector. Singapore Management Review, 26(2), 89-99

[3]. Barrows, D., \& Watson, T. (n.d.). A comparative analysis of job satisfaction among public and private sector professionals. Retrieved October 29, 2004, from: http://job-satisfaction 2.htm

[4]. Berkowitz, L., Fraser, C., \& Treasure, P. F., \& Cochran, S. (1987). Pay equity, job gratifications, and comparisons in pay satisfaction. Journal of Applied Psychology, 27, 544-551.

[5]. Bhatti, Komal k., \&Qureshi, Tahir M. 2007. Impact of employee participation on job satisfaction, employee commitment and employee productivity. International Review of Business research papers, vol.3 no. 2 June 2007

[6]. Khalid Salman \&Irshad Muhammad,( 2011) “Factor Affecting Job Satisfaction” Journal of Management Research, 6(2), 84101.

[7]. Lethal C (2007) “ The Impact of Educational level on Female Employees Job Satisfaction” ". Journal of Community Guidance. 18 (3) ,pp. 365-372.

[8]. MasudIbnRahman (2008). "The Measurement of Satisfaction in Work and Retirement”, Chicago: Rand-McNally.

[9]. Patel,M.K.(1999). A study of impact of age on job involvement and organizational commitment of Nationalized and Cooperative bank employees. Journal of Indian Academy of Applied Psychology.25(1-2),pp.65-70

[10]. Robbins and Sanghi (2006). “Job Satisfaction” New York: John Wiley \& Sons.

[11]. Sargent and Hannum (2005) . “ job satisfaction public sector bank employees "[Electronic version]”. Public Administration Quarterly, 17(1), 68-84.

[12]. Singh. G. Janak and NamitaDewans (2003): "Job satisfaction among bank emloyees."

[13]. Indian Journal of Banking Review. Vol 24. No. 2.

[14]. Yasir, K., and Fawad, H., (2009). "Pay and Job Satisfaction: A Comparative Analysis of Different Pakistani Commercial Banks". Munich Personal Re PEc Archive, paper No. 16059.pp. 1-20.

[15]. Zeal, Anwar and Nazrul (2012. "Work Experience and relationship with Job Satisfaction”. Journal of Psychology, Vol. 132. 